\title{
Perception of farmers on soil erosion and conservation practices in Dejen District, Ethiopia
}

\author{
Tegegne Tatek Belay \\ Department of Geography and Environmental Studies, Deberetabor University, Debre Tabor, Ethiopia
}

Email address:

tatekbelay@gmail.com

\section{To cite this article:}

Tegegne Tatek Belay. Perception of Farmers on Soil Erosion and Conservation Practices in Dejen District, Ethiopia. International Journal of Environmental Protection and Policy. Vol. 2, No. 6, 2014, pp. 224-229. doi: 10.11648/j.ijepp.20140206.15

\begin{abstract}
Soil erosion is one of the major causes of land degradation that causes low agricultural productivity in Ethiopia. Though, it is a natural process, its rate has increased significantly mainly by human activity. The study was conducted in Dejen district, in Northwestern Ethiopia to assess perception of farmers on soil erosion and conservation practices. In this study, both primary and secondary data collection techniques were used. These includes interviews, focus group discussions, field observations, and questionnaires were the source of this research. The sampling technique employed in this study were stratified, purposive and simple random were applied to select sample kebele and representative households heads. A sample of 250 heads of households were used to gain insight into soil erosion perceived by farmers and conservation practices in the study area. The finding of the study shows that almost all farmers of the study area had good perception on the causes, indicators and problems of soil erosion. The main causes of soil erosion perceived by farmers in the study area were high intensity of rainfall, continuous cultivation, topography and inappropriate soil conservation practices. The major soil conservation methods implemented by farmers in the study area were terracing, diversion ditches, and contour plowing and cut of drain. This research finding also concludes that the main constraints to apply soil conservations in Dejen district were mainly related to socioeconomic and biophysical factors such as uncontrolled (free) grazing, distance between homestead and farm land and farmers' low level of the economic capacity.
\end{abstract}

Keywords: Perception of Farmers, Soil Conservation Practices, Northwestern Ethiopia

\section{Introduction}

Soil degradation in Ethiopia can be seen as a direct result of past agricultural practices in its highlands (Badege, 2001). In the high lands the processes of over cultivation, deforestation, and overgrazing lead to accelerated soil erosion (Hurni, 1993). Some of the farming practices within the highlands also encourage erosion. These include cultivation of cereal crops such as Teff and wheat, which require the preparation of a finely tilled seedbed, the single cropping of fields, and down slope final plowing to facilitate drainage. On the other hand, socio-economic and political influences, especially insecurity of land and tree tenure have discouraged farmers investing in soil conservation practices (Badege, 2001). As a result of this, soil erosion is the most immediate environmental problem facing the nation at present time.

The pressure on arable land is growing and this forces people to convert more marginal, available forest and grazing lands to arable lands. Hence, forest resources are very few and continuously decreasing both in quantity and quality. These results in firewood shortage and people are forced to use animal dung as a fuel wood substitute. The major source of organic matter is thus not brought back to the soil but used for other purposes (Ludi, 2002).

Soil erosion is the most significant ecological restriction to sustainable agricultural production, mainly under subsistence agricultural production system like Central Ethiopian highlands (Gete and Huni, 2001). Site-specific test plots and experiments in 1987 and 1988 at conservation research project (SCRP) stations in Amhara region show soil loss rates to vary between 0.04 and $212 \mathrm{t} / \mathrm{ha} / \mathrm{yr}$ (Lakew et al, 2000). The estimated soil loss rate in the region by rill and sheet erosion on cultivated land also varies from 200-300 t/ha/year. This indicated that an average of $2.5 \mathrm{~cm}$ thick soil is being displaced every year from a hectare of land (Abegaz, 1995).

Soil erosion is triggered and become a principal obstacle for sustained and integrated socio-economic development of the nation. As a result, the present status and rate of soil erosion in 
Ethiopia call for immediate action to reverse soil erosion. Hence, to protect soil resources from erosion different remedial action should be taken with the help of soil conservation mechanisms to sustain the productivity of the land.

This study was conducted in Dejen district (Central highlands of Ethiopia). The district, as one part of Amhara region, it is affected by land degradation particularly soil erosion. Farmers' perception and attitudes towards soil erosion and conservation practices is decisive in protecting soil losses from erosion. Hence, farmers' perception of soil erosion is a key social factor that is also important in deciding options for controlling soil losses (Graaff, 1993).

However, for many years, soil conservation programs in the highlands of Ethiopia were premised on the notion that farmers did not perceive erosion and had little or no interest in combating it (Mekuria, 2005). Most soil and water conservation planning approaches rely on empirical assessment methods by experts and hardly consider farmers knowledge of soil erosion. As a result, conservation programs and approaches performed poorly (Yohannes and Herweg, 2000). In Dejen district both traditional and modern methods of soil conservation are used by local farmers with different proportions. For selecting and implementing appropriate conservation methods, it is important to identify constraints that affect farmers to adopt or apply both traditional and modern soil conservation methods and their farming practices. Therefore, this present study was designed to assess farmers' perception about soil erosion and conservation practices in Dejen district, Northwestern Ethiopia.

A review of the relevant literature points to the fact that a number of empirical studies have been undertaken on perception of farmers on soil erosion and conservation practices, the existing soil conservation practices adopted by farmers on their farms and pasture lands and the socio-economic, bio-physical, policy and institutional related constraints influencing farmers' perceptions to implement different soil conservation practices in the Ethiopian context.

However, nearly all of them have been addressing issues of adoption in relation to improved production technologies. Available evidence shows that studies on the determinants of adoption of soil conservation measures are few and far between. Therefore, this study was conducted in view of bridging this gap.

The objectives of this study were to assess how farmers' perceive soil erosion problems and the causes that trigger soil erosion problems, identify the existing soil conservation practices adopted by farmers on their farms and pasture lands and examine the socio-economic, bio-physical, policy and institutional related constraints influencing farmers' perceptions to implement different soil conservation practices.

\section{Materials and Methods}

\subsection{Description of the Study Area}

The study was carried out in Dejen district, East Gojjam zone, Amhara regional state. Dejen is situated at $230 \mathrm{~km}$ northwest of the capital city of Ethiopia, Addis Ababa.

The annual average temperature and total annual rainfall of the district ranges between $20^{\circ} \mathrm{C}$ and $24^{\circ} \mathrm{C}$ and $800 \mathrm{~mm}$ and $1200 \mathrm{~mm}$, respectively. On the basis of altitudinal variation, the district has been categorized into three traditional climatic zones i.e., Kolla (Tropical), Woinadega (Sub-tropical) and Dega (Temprate) having elevation 1000-1500m, 1500-2500m and 2500-3000m above sea level, respectively.

The topography of the district contains mountainous (28.2\%), pla-in (60\%) and depressions (11.8\%). It has altitude ranging from $1000 \mathrm{~m}$ to nearly $3000 \mathrm{~m}$ above sea level. The district is characterized by rugged terrain and plain surfaces. Those kebele which are found in the valley of the Blue Nile have highly undulated topography consisting of hilly lands and ridges. On the other hand, those which are found out of the valley have flat topography. The district is endowed with rivers including Abay River and its tributaries i.e. Soha watershed, Muga watershed and Bechet watershed (Dejen District Agricultural and Rural Development office, 2011).

Dejen district has various types of vegetation in response to the variation of soils, climate and human activities. At present time, matured and naturally grown trees are observed only in the old church compounds and in some homesteads. In the remaining areas, natural vegetation is very much degraded, Some of the major indigenous tree/shrub species which still survive in the area include "Warka" (Ficus vaita), "Bisana" (Croton macrostachyus), "Cheba" (Acacia nilotica), "Digetta" (Calpurnia aurea), "Woira" (Olea Africana), etc. In addition, important exotic tree/shrub species such as "Nech bahirzaf" (Eucalyptus globules), "Key bahirzaf" (Eucalyptus camaldulesis), and "Yeferenge tid" (Cupressus lustanica) are commonly observed in the area.

Based on Dejen district agriculture and rural development office (2011), the total area of the district was estimated to be 62767 hectares $\left(627.67 \mathrm{~km}^{2}\right)$. The cultivated land is the dominant land use type, which accounts 33147 hectares $(52.8 \%)$, while $34.6 \%, 11.88 \%$ and $0.72 \%$ were covered by settlement and construction, grazing land, and unused (wasted) land, respectively.

\subsection{Sampling Techniques}

The sampling technique employed in this study were stratified, purposive and simple random sampling techniques. Based on the information obtained from Dejen district agricultural and rural development office and preliminary field survey the district has three agro-ecological zones. Then in the first stage the rural administration kebele of the district were stratified into three strata based on their agro-ecological zones i.e., kolla (Tropical), Woinadega (sub-tropical) and Dega (temprate). Then, the researcher purposely selected one kebele from each agro-ecological zone by simple random sampling from the total kebele. After having the list of household $(\mathrm{HH})$ of the farmers' in these selected kebele, sample size was determined proportionally to its number of kebele households.

Hence, a total of 250 household farmers' were selected by using simple random sampling techniques from their available 
list of names of rural kebele administration office. The reason for deciding on this sample size was the homogeneity of the households in their social and cultural aspects is more representative to the rest of the population, and considering time and cost of the research work. A considerable proportional share of male and female household were treated in each agro-ecological zone.

\subsection{Methods of Data Analysis}

In order to address the specified objectives and to answer the given research questions, the study analyzed, summarized, and presented the data both qualitatively and quantitatively. The qualitative method was employed to analyze the opinions of farmers and substantiate the quantitative data obtained through questionnaires survey. Specifically, the quantitative data were analyzed, summarized, and presented in the form of tables, graphs and percentage by using appropriate descriptive statistics.

\section{Results and Discussion}

\subsection{Perception of Farmers' about the Causes and Indicators of Soil Erosion Problems in the Study Area}

Throughout the discussion perception of farmers on the causes of soil erosion were very familiar. From the finding as farmers of the study area said that some of the main causes of soil erosion problems of Dejen district perceived by farmers were the slope of the land, deforestation, improper farming practice and high intensity of rainfall and absence of appropriate soil conservation practice.

Moreover, based on the focus group participates and key informants of the study area farmers perception of soil problems refers to the perception to relationship and processes of soil erosion, and fertility of the soil. The surveyed households were asked about the indicators of soil erosion problem on their own farm plots, $45.3 \%$ of farmers reported that the presence of gullies and rills as a major indicator on their cultivated plot and communal grazing land. The rest, $37.3 \%$ and $17.4 \%$, of farmers also reported that the decline of agricultural productivity of their farm plots and the change of soil color were the indicators of soil erosion, respectively. This perception of the farmers is most closely associated with the scientific finding of most researchers.

According to the survey result, soil erosion was severe on farm plots and communal grazing lands at rainy or summer season locally called "kiremit". This shows that the major causes of soil erosion in the study area is water erosion.

The study showed that the majority $(89 \%)$ of farmers' stated that livestock have contribution for soil erosion process, whereas $11 \%$ of household farmers reported that live stocks have no contribution for soil erosion process.

\subsection{Major Soil Conservation Practice Implemented by Farmers in the Study Area}

According to the finding of the survey, all of household farmers agreed that soil conservation practices are important to minimize the rate of soil erosion on farm plots and communal grazing lands. This shows that all house hold farmers had good perception towards the importance of soil conservation methods on farm plots and communal grazing lands. All of house hold farmers stated that they use both traditional and introduced soil conservation methods on their own farm plots to prevent soil erosion and enhance soil fertility.

According to the survey results there are various soil conservation practices applied by farmers on their own farm plots and grazing lands erosion control methods used in the study area include, plantation of trees, contour plowing, check dams, soil and stone bunds, diversion ditches (cut of drain) locally called "feses", crop rotation and terracing. The most important conservation structures widely used in the area include, contour plowing, diversion ditches (cut of drain) locally called "Yegorif mekelibesha boyi or feses", crop rotation and terracing.

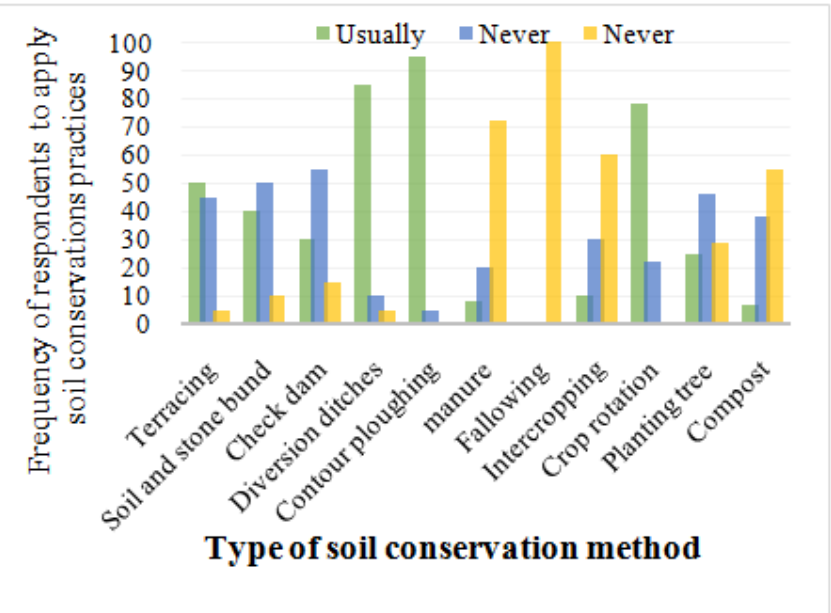

Figure 1. Farmers' response regard to the major soil conservation methods they implemented

Contour plowing-cultivating crops on the contour where the slope was steep is one of the major soil conservation practice applied in the study area. Most of the farmers, as focus group participants reported and interviewees said, they used contour ploughing in order to minimize runoff and erosion on their farm plots.

Crop Rotation- the use of crop rotation is another widespread phenomena in the area where teff, wheat, vetch, maize, chickpea, sorghum, lentils and barley rotationally. Crop rotation is used by the farmers important for different reasons including soil moisture and soil fertility, thus improved crop yield. The farmers of the area know that as of the scientific method improved soil fertility can be achieved by alternating high residue producing crops with the growing low residue producing crops.

Soil (stone) bund is an embankment or ridge built across a slope along the contour. Soil bunds are made of soil or mud. On moderately sloping areas the farmers construct the soil and stone bunds for erosion control but most of the time farmers of the study area used stone bund structures instead 
of soil bund. As the key informants stated that if shortage of stone is exist on their farm area they were used soil bunds structures. As it is stated by key informants during focus group discussion the stone bund are considered effective in erosion control.

Cut off drains-Locally called by farmers "Yegorif mekelibesha boyi or feses" are one of the physical structure constructed by tilling or digging the soil deep in order to divert the runoff before reaching the farmland to discharge flow of water into river channel or stream channel.

According to the data obtained from respondents, there were also recently adopted soil conservation methods were, application of micro basin, eyebrow basin and fanya juu. As the focus group participants (FGPs) explained the newly introduced soil conservation methods were not used before by farmers of the study area. As a result of this, such types of conservation practices were not implemented easily by house hold farmers as a result of this most of the time they used the recent soil conservation practices integrated with the indigenous soil conservation methods to conserve the soil effectively.

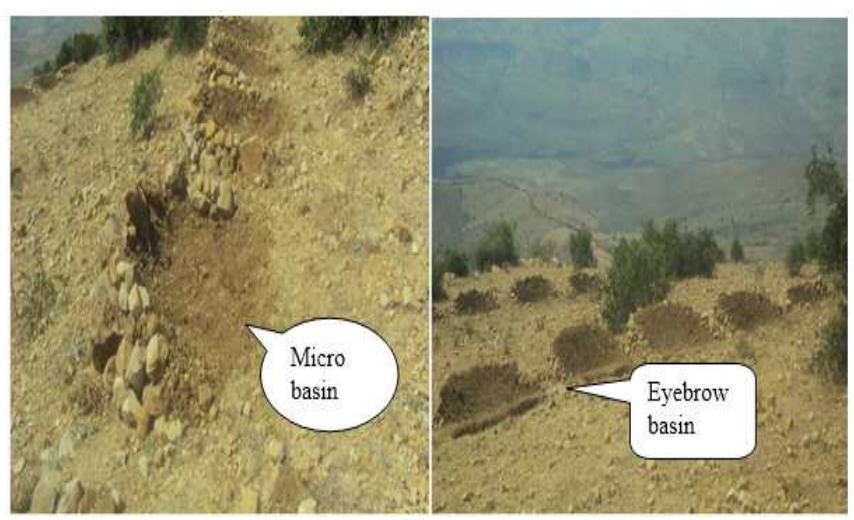

Figure 2. The newly introduced soil and water conservation practices

\subsection{Factors that Affect Farmers to Apply Soil Conservation Methods in the Study Area}

Globally, soil erosion associated with agricultural land is more widespread than that associated with other land uses. Erosion control is therefore strongly influenced by the factors that encourage or discourage farmers from adopting soil conservation practices (Morgan, 2005). According to Aklilu (2006), the adoption of soil conservation practice is influenced by farmers' age, farm size, perceptions on technology profitability, slope, livestock size and soil fertility, and the decision to continue using the practice is influenced by actual technology profitability, slope, soil fertility, family size, farm size and participation in off-farm work.

Woldeamilak (2002) also stated that perception of soil erosion as a hazard to crop production and sustainable agriculture is the most important determinant factor for adoption of conservation measures and understanding and recognition of soil erosion as a problem in their own farm plots, and its causes and impacts on crop yields is the first step towards searching of and adoption of remedial measures.
Thus, the implementation of soil conservation practices by house hold farmers on their own farm plots is influenced by a combined effect of socio-economic, bio-physical, institutional and policy related factors.

\subsubsection{Socio-Economic Factors}

Based on the research finding the socio-economic constraints affecting farmers to apply soil and water conservation in the study area were human labor force, farm experience, lack of economy to sustain their life and farm size of farmers had. According to the research finding these factors affect farmers both positively and negatively to apply soil and water conservation practices. As the key informants of group discussion participants stated that farm experience of soil conservation works makes a difference doing either in the farmers' perception of soil erosion problem. Further, this finding asserts that farmers with experiences of one or more of the soil conservation practices (e.g. terracing, check dam, diversion ditches, contour plowing and crop rotation, etc.) already had the experience and they were more aware of soil erosion problem than farmers who did not have any experience of doing soil and water conservation practices.

According to the interviewee conducted with the district agricultural and rural development head he thought that farmers who had adequate farm experience have better knowledge than farmer who had fewer farm experience concerning the influence of run off on agricultural field and how they control so that experienced household farmer could use appropriate soil conservation methods at appropriate time and place compared with less farm experienced farmer.

Based on the data obtained from focus group participants of the study area when they asked how economy determines farmers to implement soil conservation methods on their farm plots and grazing or communal lands, they explained that economically low house hold farmers who have low capacity to buy artificial fertilizer and who do not have ox to plow their own farm area rent sometimes for one-two year or for share cropping for other economically better farmers. Therefore, the rental farmers do not apply soil conservation methods on the rented and share cropping farm plot to use farms in a sustainable way because they only assumed the short term production of a particular year and do not worry about the long term effect of absence of soil conservation method on farm plot. Moreover, economically poor farmers have no capacity to make manure and compost to enhance the fertility of their own agricultural field. This is similar to the investigation of Elni (2006), the researcher examined that rich farmers are more involved in the maintenance and implementation of conservation methods than farmers who have low income.

\subsubsection{Bio-Physical Factor}

The other factor that affect farmers in the study area to apply soil and water conservation practice is related to bio-physical factors such as topographic condition of the land, distance between home area and farm plot, high intensity of rainfall and uncontrolled or free grazing. Most of the Focus group participants thought that farmers who had more farm 
plot did not apply/use soil conservation structures. As they stated farmers who hold more farm area expect more production from large farm size so that they do not give emphasize to a particular farm plots to conserve effectively and to use in a sustainable way. Moreover, most of their farm plots are located at different or scattered places and the distance between farm plots is far away from their home. As a result of this, they do not have a chance to observe their farm plot daily or even for week. Hence, the ignored cultivated plot could be eroded by sudden run runoff if the cut of drain or other soil conservation practices destroyed by run off at the time of high intensity of rainfall.

Table 1. Response of household farmers regarding to Bio-physical factors that influence them to use soil conservation practices

\begin{tabular}{lll}
\hline Biophysical factors that affect farmers to & \multicolumn{2}{c}{ Number of respondents } \\
\cline { 2 - 3 } implement soil conservation methods & Frequency & $\%$ \\
\hline Topographic conditions of the land and & 57 & 22.80 \\
severity of rainfall & 60 & 24.00 \\
Farm size & 68 & 27.20 \\
Distance between home area and farm plot & 65 & 26.00 \\
\hline Free (uncontrolled) grazing & \\
\hline
\end{tabular}

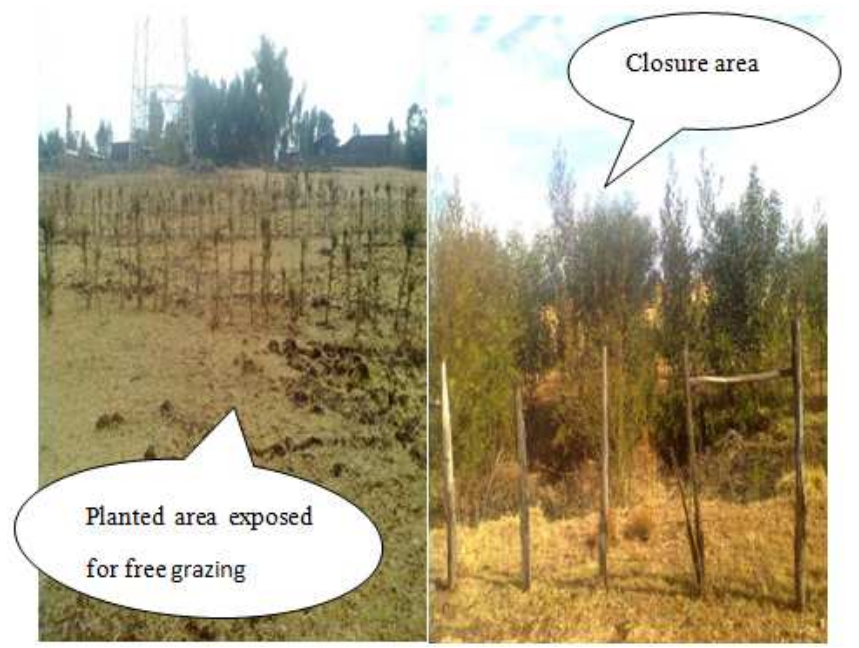

Figure 3. The left shows the planted tree rambled by uncontrolled grazing (Sesbania or Sesbania bispinosa tree affected by free grazing and the right shows closure area from livestock contact at different study sites.

\section{Conclusion}

Based on the above findings, the following conclusions could be drawn:

Soil erosion is a threat to the economic development of Ethiopia in general and in Dejen district in particular. As farmers are dependent on the agricultural sector for their livelihood, assessing perception of farmers on soil erosion and conservation practices has become very important.

Regarding this, the researcher analyzed the perception of farmers on soil erosion problem and causes of soil erosion, the major soil conservation practices implemented by farmers and factors influencing farmers to apply soil conservation methods on their farm plots and grazing or communal lands in three sample kebele of Dejen district.

Throughout the discussion perception of farmers on the causes of soil erosion were very familiar from the finding as farmers of the study area said that some of the main causes of soil erosion problems of Dejen district perceived by farmers were the slope of the land, deforestation, improper farming practice and high intensity of rainfall and absence of appropriate soil conservation practice.

The surveyed households were asked about the indicators of soil erosion problem on their own farm plots, $44.3 \%$ of farmers reported that the presence of gullies and rills as a major indicator on their cultivated plot and communal grazing land. The rest, $37.3 \%$ and $17.4 \%$, of farmers also reported that the decline of agricultural productivity of their farm plots and the change of soil color were the indicators of soil erosion, respectively.

The study identified that farmers of the study area applied the soil conservation practices on their own farm areas. The major soil conservation practices which have been applied by farmers were contour plowing, diversion ditches, crop rotation, terracing and cut of drain. Accordingly, most farmers of the study area have not applied other type of soil conservation methods such as fallowing, strip-cropping, compost and manure on their cultivated plots. As the focus group participants indicated, there were different types of newly introduced soil conservation methods in the study area. Nevertheless, these had not been applied by farmers on their own farm areas rather they were used on communal or grazing areas enforced by the extension workers.

As stated by farmers response, focus group participants and key informants, the main determinant factors for farmers' decision to apply soil conservation methods on their cultivated plot and grazing lands were related with socio-economic, bio-physical and institutional and policy issues. These included low level of economy, farm size, topographic condition of the land, distance between home area and farm plot, high intensity of rainfall and uncontrolled or free grazing.

As revealed by FGPs, farmers who cultivated their own land (obtained from the kebele or inherited from parents) implement soil conservation as compared to those who rented or cultivated land for share crop. This could be due to the fact that farmers who cultivated their own farmland were more secured to implement sustainable soil conservation practices compared to those who rented.

\section{Recommendations}

To realize the goal of achieving sustainable use of the land in general and the soil resource in particular in the study area, insights gained from the study suggest a number of issues to be considered in the area of soil erosion and conservation practices. The following important points need to be considered.

Any concerned body or organization such as district agricultural and rural development office, extension worker supervisor, development agents, etc. should disseminate education to the whole farmers about the introduced or newly and traditional soil conservation methods to promote the perception and awareness of farmers about the effect of soil 
erosion on the whole lands (both on farm areas and communal or grazing lands), which enabled the farmers to adapt and implements soil conservation practices effectively.

Integrating soil conservation measures of the local people with the newly introduced soil and water conservation practices. That can improve the indigenous knowledge system of soil conservation and the possibility of integration between indigenous knowledge systems with some modern/scientific/ knowledge rather than totally dependent on the indigenous knowledge of the farmer. This is because integrating indigenous soil and water conservations with that of the modern/newly introduced soil conservation practice is very crucial for an improved livelihood and sustainable land use.

Economically poor farmers in the study area rent their own farm lands for other economically better farmers. This in turn influenced the implementation of conservation practices negatively. Thus, the concerned bodies need to investigate the issue and take appropriate measures. For instance, the expansion of credit and saving would increase farmers' capacity to cultivate their own farm land and implement soil conservation methods.

The district agricultural and rural development and other sector officers, local administrative leaders and farmers should draw rules and regulations that govern farmers to protect soil erosion, uncontrolled grazing and deforestation to use the farm plots and communal or grazing lands by applying sustainable soil conservation methods.

\section{References}

[1] Abegaz G. (1995). Soil erosion assessment: Approaches, magnitude of the problem and issues on policy and strategy development (Region 3). Paper presented at the Workshop on Regional Natural Resources Management Potentials and Constraints, Bahir Dar, Ethiopia.
[2] Aklilu A. (2006). Caring for the land Best practices in soil and water conservation in Beressa watershed highlands of Ethiopia. Ph.D.thesis, Wageningen University, Netherlands.

[3] Badege B. (2001). Deforestation and Land Degradation in the Ethiopian highlands: A Strategy for Physical Recovery. Corvallis, Oregon state university.

[4] Elni T. (2008). Continued Use of Soil and Water Conservation Practices: a Case study in Tulla District, Ethiopia, MSc Thesis, Wageningen University.

[5] Gete Z., and Hurni, H. (2001). Implications of Land Use and Land Cover Dynamics for Mountain Resource Degradation in the Northwestern Ethiopian Highlands: Journal of Mountain Research and Development, 22,184-191.

[6] Graaff J.D., (1993). Soil conservation and sustainable land use: An economic approach Royal Tropical Institute, Amsterdam. Ethiopia: The agricultural sector: an overview, vol. 2 and 1, FAO, Rome.

[7] Herweg, K., and Yohannes G.M. (2002). Adaptation or adoption? -Integrating different perceptions of soil and water conservation in Ethiopia. In: M., Flury and U.,Geiser (eds), Local environmental management in a North-South perspective: issues of participation and knowledge management (pp. 181-190)

[8] Lakew D., Kassie M., Benin S., and Pender J. (2000) Land Degradation and Strategies for sustainable development in the Ethiopian highlands: Amhara Region, socio- economics and Policy Research Working paper 32. ILRI, Nairobi, Kenya.

[9] Mekiura A. (2005). Forest Conversion, Soil degradation, Farmers' perception nexus: Implications for Sustainable land use in the southwest of Ethiopia, Ecology and Development serious No. 26, CuvillierVerlag, Gottingen.

[10] Morgan, R.P.C. (2005). Soil Erosion and Soil Conservation $3^{\text {rd }}$ ed: Blackwell Publishing Company. Oxford, UK.

[11] Yohannes G.M and Herweg, K. (2000). From indigenous knowledge to participatory technology development: Centre for Development and Environment (CDE), University of Bern. 